\title{
PENGEMBANGAN BAHAN AJAR ELEKTRONIK BERBASIS FLIPBOOK MAKER PADA MATERI PROGRAM LINEAR KELAS X SMK
}

\author{
Wulan Noviyanita \\ Program Studi Pendidikan Matematika FKIP UNIKAL \\ Jl. Sriwijaya No 3 Pekalongan, \\ wulwul.5656@gmail.com
}

\begin{abstract}
Abstrak
Kegiatan pembelajaran di SMK Muhammadiyah Kesesi masih kurang memanfaatkan media pembelajaran, guru masih menggunakan buku paket yang tersedia di sekolah serta power point pada saatpembelajaran sehingga siswa merasa jenuh. Penelitian ini mengembangkan bahan ajar elektronik berbasis flipbook maker pada materi program linear kelas X di SMK Muhammadiyah Kesesi. Tujuan dari penelitian ini adalah untuk mengetahui kevalidan dan kepraktisan bahan ajar elektronik yang dikembangkan. Penelitian yang dilakukan menggunakan model pengembangan Borg \& Gall yang termuat dalam Putra (2012:120-121). Langkah-langkah penelitian tersebut yaitu 1) penelitian danpengumpulan data; 2) pengembangan jenis/bentuk produk awal; 3) uji coba lapangan tahap awal; 4) uji pelaksanaan lapangan; 5) penyempurnaan produk. Berdasarkan hasil penelitian diperoleh rata-rata total kriteria dari validator $V_{a}=4,1$. Menurut kriteria validasi maka dapat disimpulkan bahwa bahan ajar elektronik berbasis flipbook maker pada materi program linear kelas X SMK dikatakan valid. Sedangkan hasil perhitungan nilai kepraktisan bahan ajar elektronik berbasis flipbook maker pada materi program linear kelas X SMK yang diperoleh dari angket respon siswa adalah 85,9\%. Hal tersebut berarti bahwa bahan ajar elektronik yang dikembangkan dinyatakan praktis. Oleh karena itu, dapat disimpulkan bahwa bahan ajar elektronik berbasis flipbook maker pada materi program linear kelas X SMK layak digunakan sebagai salah satu sumber belajar.
\end{abstract}

Kata Kunci : Bahan Ajar Elektronik, Flipbook Maker, Program Linear.

\begin{abstract}
Learning activities at SMK Muhammadiyah Kesesi are still less use of instructional media, teachers still use the available package books in school and power point at the time of learning so that students feel ored. This research develops electronic teaching materials based on flipbook maker linear class $\mathrm{X}$ material program at SMK Muhammadiyah Kesesi. The purpose of this research is to know the validity and the practicability of the developed electronic materials. The research conducted using the Borg \& Gall development model included in Putra (2012:120-121). The steps of the research are: 1) research and data collection; 2) development of initial product type / shape; 3) initial field trials; 4) field implementation test; 5) product improvement. There are 8 validator in this research and there are 28 students as respondent. Based on the research results obtained the average total criteria from the validator $V_{a}=4,1$. According to the validation criteria, it can be conclud that the electronic teaching materials using kvisoft flipbook maker application on the material linear, class X SMK is said to be valid. While the calculation of the value of the practicality of electronic materials using kvisoft flipbook maker application on material linear class X SMK obtained from the student response questionnaire is $85,9 \%$. It means, the developed electronic teaching material is declared practical. Therefore, it can be concluded that the electronic teaching materials using kvisoft flipbook maker application on material linear class X SMK is suitable to use as one of the learning resources.
\end{abstract}

Keywords: Electronic Teaching Materials, Kvisoft Flipbook Maker, Linear Program.

\section{Pendahuluan}

Tantangan di dunia pendidikan pada zaman sekarang lebih kompleks, sebab adanya program 
masyarakat Ekonomi ASEAN (MEA) mengharuskan Sumber Daya Manusia (SDM) masyarakat lebih siap bersaing di era global. Upaya yang tepat untuk menyiapkan SDM yang berkualitas dan satu-satunya wadah yang dapat dipandang dan seyogianya berfungsi sebagai alat untuk membangun SDM yang bermutu tinggi adalah pendidikan (Trianto, 2009:4). Pendidikan adalah salah satu bentuk perwujudan kebudayaan manusia yang dinamis dan syarat perkembangan (Trianto,2009:1). Menurut Undang-Undang Nomor 20 Tahun 2003 tentang Sistem Pendidikan Nasioanl menyebutkan, bahwa pendidikan bertujuan untuk mengembangkan potensi siswa agar menjadi manusia yang beriman dan bertakwa kepada Tuhan Yang Maha Esa, berahlak mulia, sehat, berilmu, cakap, kreatif, mandiri, dan menjadi warga negara yang demokrasi serta bertanggung jawab (Trianto, 2009:1). Salah satu yang menunjang perkembangan potensi siswa yaitu melalui pendidikan formal. Sistem yang mendukung dalam pendidikan formal salah satunya adalah terdapat mata pelajaran. Mata pelajaran yang dipelajari siswa disetiap jenjang pendidikan itu salah satunya adalah pelajaran matematika.

Menurut Hermer dan Trueblood dalam Sam's (2010:13) konsep matematika tersusun menurut hirarki yang mempunyai arti bahwa konsep yang satu merupakan landasan atau dasar bagi konsep berikutnya. Pendapat Herman dalam Sam's (2010:13) mengenai konsep matematika yaitu mempelajari konsep B yang mendasarkan kepada konsep A, seseorang perlu memahami lebih dahulu konsep A. Berdasarkan penjelasan tentang konsep matematika, jika hal tersebut diterapkan di sekolah setiap jenjang pendidikan maka tidak ada lagi siswa yang kesulitan memahami konsep matematika.

Fenomena yang terjadi pada jenjang pendidikan di sekolah, banyak siswa mengalami kesulitan dalam mempelajari matematika (Jhonson dan Hamonangan, 2014:98). Berdasarkan hasil wawancara dengan guru matematika di SMK Muhammadiyah Kesesi, menurut guru hampir setiap siswa merasa jenuh dalam pembelajaran matematika karena siswa menganggap matematika pelajaran yang sulit. Hal tersebut terbukti ketika dilakukan observasi sekitar 70\% siswa merasa jenuh dalam pembelajaran matematika. Rasa jenuh siswa ditunjukkan dengan sikap ketika mengikuti pembelajaran matematika siswa ngobrol dengan temannya dan kurang memperhatikan Guru menjelaskan. Wawancara juga dilakukan pada salah satu siswa, menurut siswa pelajaran matematika itu sulit dan ketika guru menjelaskan siswa jarang memperhatikan karena merasa jenuh.

Pengumpulan data tidak hanya dilakukan dengan cara wawancara tetapi, dengan cara observasi juga untuk menambah data yang dikumpulkan. Hasil observasi yang didapat yaitu 
siswa kurang aktif selama pembelajaran matematika, guru di SMK Muhammadiyah Kesesi kurang pemanfaatan media, guru masih menggunakan buku paket yang tersedia di sekolah serta power point, kurikulum yang digunakan di SMK Muhammadiyah Kesesi yaitu Kurikulum Tingkat Satuan Pendidikan (KTSP), di sekolah terdapat laboratorium komputer tetapi proses pembelajaran matematika belum pernah memanfaatkan fasilitas tersebut, dan di SMK Muhammadiyah Kesesi sudah tersedia LCD proyektor dan speaker yang siap untuk dipakai dalam proses pembelajaran. Fasilitas yang sudah tersedia di sekolah belum dimanfaatkan dengan maksimal dalam proses pembelajaran.

Kecenderungan pembelajaran yang kurang membuat siswa tertarik merupakan hal yang wajar dialami guru jika belum bisa memahami karakteristik siswa (Daryanto, 2013:2). Hal tersebut ditemui di SMK Muhammadiyah Kesesi, sebab guru matematika di SMK masih baru perlu penyesuaian. Berdasarkan data di SMK Muhammadiyah Kesesi pada nilai ulangan harian materi program linear tahun lalu, 45\% siswa belum mencapai nilai KKM (Kriteria Ketuntasan Minimal) yang ditentukan yaitu 75. Hal tersebut disebabkan karena siswa belum paham dengan konsep program linear yang dijelaskan guru.

Menurut Daryanto (2013:1) prestasi belajar siswa di sekolah sering diindikasikan dengan permasalahan belajar dari siswa tersebut dalam memahami materi. Guru perlu mengetahui mengenai strategi pembelajaran supaya bisa melaksanakan pembelajaran yang tepat. Pemilihan strategi pembelajaran yang sesuai merupakan daya dukung bagi siswa untuk dapat mencapai prestasi gemilang dalam bidang matematika (Jhonson dan Hamonangan, 2014:99). Oleh karena itu, perlu adanya upaya merancang strategi pembelajaran yang tepat yaitu dengan menciptakan suasana pembelajaran matematika yang menarik agar tidak membuat siswa jenuh serta dapat meningkatkan hasil belajar siswa. Menciptakan suasana pembelajaran tersebut serta meningkatkan hasil belajar siswa maka perlu adanya persiapan meliputi 1) pemilihan metode pembelajaran yang sesuai dengan materi sehingga dapat meningkatkan motivasi belajar siswa; 2) menyiapkan sebuah bahan ajar menarik yang mendukung proses pembelajaran.

Metode pembelajaran yang bisa dipilih banyak, salah satu metode pembelajaran yang dapat dipilih yaitu metode Cooperative Integrated Reading And Composition (CIRC). Menurut Sutrisno CIRC merupakan salah satu tipe model pembelajaran cooperative learning. Menurut Slavin dalam Halimah (2014:34) metode CIRC mempunyai kelebihan diantaranya yaitu 1) model pembelajaran kooperatif tipe CIRC amat tepat untuk meningkatkan pemahaman siswa pada materi pembelajaran; 2) siswa termotivasi pada hasil secara teliti karena bekerjasama dalam 
kelompok; 3) meningkatkan hasil belajar, khususnya dalam menyelesaikan soal yang diberikan guru. Tidak hanya pemilihan metode pembelajara, tetapi bahan ajar yang digunakan pada proses pembelajaran juga perlu dipersiapkan.

Menurut Daryanto dan Dwicahyono (2014:171) bahan ajar merupakan informasi, alat dan teks yang diperlukan guru atau instruktur untuk perencanaan dan penelaahan implementasi pembelajaran. Manfaat bahan ajar bagi guru salah satunya yaitu guru tidak lagi bergantung kepada buku teks yang terkadang sulit diperoleh dan salah satu manfaat bagi siswa adalah kegiatan pembelajaran lebih menarik (Daryanto dan Dwicahyono, 2014:172). Pemanfaatan kemajuan teknologi dapat mendukung kegiatan pembelajaran, misalnya membuat bahan ajar yang menarik dengan sebuah aplikasi. Menurut Sugianto, dkk (2013:101) dengan memanfaatkan kemajuan teknologi salah satunya teknologi multimedia telah menjanjikan potensi besar dalam merubah cara seseorang untuk belajar, untuk memperoleh informasi, menyesuaikan informasi dan sebagainya.

Salah satu teknologi yang diharapakan dapat menciptakan suasana belajar menarik dan mudah dipahami yaitu dengan memanfaatkan penggunaan sebuah aplikasi kvisoft flipbook maker. Apliksi kvisoft flipbook marker merupakan perangkat lunak atau software yang digunakan untuk membuat tampilan buku atau bahan ajar lainnya menjadi sebuah buku elektronik digital berbentuk flipbook (Sugianto dkk, 2013:103).

Berdasarkan penelitian yang dilakukan oleh Wahyudi pada tahun 2012 dapat disimpulkan bahwa bahan ajar elektronik multimedia dengan macromedia flash 8.0 yang dibuat memiliki kategori yang baik dari segi materi maupun media. Penelitian lain yang dilakukan oleh Liana pada tahun 2014 memberi kesimpulan bahwa $t_{\text {hitung }}>t_{\text {tabel }}$ yaitu 4,125> 1,6696667 maka, hipotesis $\mathrm{H}_{0}$ ditolak, jadi rata-rata nilai hasil belajar siswa yang menggunakan modul pembelajaran berbantu flipbook maker dengan model TSTS lebih baik dari rata-rata nilai hasil belajar siswa yang menggunakan pembelajaran konvensional. Hal tersebut menunjukkan pembelajaran kelas eksperimen mencapai efektif. Jadi validitas perangkat dan efektifitas pembelajaran tercapai. Berdasarkan pemaparan hasil penelitian yang sudah dilakukan sebelumnya, terdapat variasi media yang dikembangkan dan variasi aplikasi yang digunakan untuk membuat media. Oleh karena itu, dari beberapa variasi di atas penelitian ini mengambil salah satu dari beberapa variasi tersebut. Penelitian ini mengambil pengembangan bahan ajar elektronik berbasis flipbook marker pada materi program linear kelas X SMK.

Adapun tujuan dari penelitian ini adalah: 
1. Mengetahui kevalidan pengembangan bahan ajar elektronik berbasis flipbook marker pada materi program linear kelas X SMK.

2. Mengetahui kepraktisan pengembangan bahan ajar elektronik berbasis flipbook marker pada materi program linear kelas X SMK.

\section{Metode Penelitian}

Penelitian ini merupakan penelitian pengembangan. Penelitian pengembangan (Research and Development) adalah penelitian yang digunakan untuk menghasilkan produk tertentu, dan menguji keefektifan produk tersebut (Sugiyono, 2010:407). Model pengembangan yang digunakan pada penelitian ini adalah model menurut Borg \& Gall dalam Putra (2012: 120- 121). Prosedur penelitian pengembangan dalam penelitian ini adalah sebagai berikut : 1) penelitian dan pengumpulan data; 2) pengembangan jenis/bentuk produk awal; 3) uji coba lapangan tahap awal; 4) uji pelaksanaan lapangan; 5) penyempurnaan produk.

Penjelasan mengenai prosedur penelitian pengembangan dalam penelitian ini sebagai berikut.

1) Penelitian dan pengumpulan data

Penelitian ini dilakukan di SMK Muhammadiyah Kesesi. Pengumpulan data dilakukan dengan cara pengamatan di dalam kelas selama proses pembelajaran dan wawancara ke siswa dan guru matematika. Beberapa permasalahan yang ditemukan, penelitian ini memfokuskan pada masalah terbatasnya media maupun alat bantu yang dapat mendukung proses pembelajaran. Oleh karena itu, penelitian ini mengembangkan sebuah bahan ajar elektronik berbasis flipbook maker pada materi program linear kelas X SMK.

2) Pegembangan jenis/bentuk produk awal Tahap

pengembangan jenis/bentuk produk awal dimulai dengan membuat draf bahan ajar elektronik, kemudian mendesain bahan ajar elektronik di microsoft word, selanjutnya didesain menggunakan aplikasi kvisoft flipbook maker.

3) Uji coba lapangan tahap awal

Uji coba lapangan tahap awal merupakan proses pengumpulan data atau proses validasi dengan menggunakan angket. Validasi produk dilakukan dengan cara menyerahkan lembar validasi kepada 8 validator untuk menilai valid atau tidak bahan ajar elektronik yang dibuat. Lembar validasi yang dinilai oleh 8 validator memuat 4 kriteria dan 28 pernyataan.

4) Uji pelaksanaan lapangan

Setelah produk melalui uji coba lapangan tahap awal, produk yang dikembangkan 
direvisi kekurangannya sesuai masukan dari 8 validator. Produk bahan ajar elektronik yang sudah direvisi, kemudian diuji pelaksanaan lapangan untuk mengetahui kepraktisannya. Uji pelaksanaan lapangan dilakukan di salah satu kelas X SMK Muhammadiyah Kesesi. Kepraktisan bahan ajar elektronik yang dikembangkan dapat dilihat melalui angket respon siswa setelah menggunakan bahan ajar elektronik. Angket respon siswa memuat 4 kriteria dan 20 pernyataan.

5) Penyempurnaan produk

Setelah uji pelaksanaan lapangan pemakaian bahan ajar elektronik dilakukan, maka bahan ajar elektronik yang dikembangkan disempurnakan atau diperbaiki sesuai dengan saran perbaikan yang diberikan dari siswa pada saat uji coba.

\section{Hasil dan Pembahasan}

Berdasarkan hasil observasi di SMK Muhammadiyah Kesesi diketahui permasalahannya yaitu keaktifan siswa kurang dalam pembelajaran matematika serta kurangnya pemanfaatan media pembelajaran, guru masih menggunakan buku paket yang tersedia di sekolah dan power point. Selanjutnya, hasil wawancara ke siswa serta guru matematika didapatkan hasil yaitu siswa merasa jenuh ketika pembelajaran matematika, kondisi kelas yang kurang kondusif serta keterbatasan media yang digunakan dan guru jarang menggunakan media. Berdasarkan pengumpulan data tambahan diperoleh bahwa nilai rata-rata ulangan siswa tahun lalu pada materi program linear kurang dari KKM (Kriteria Ketuntasan Minimal) yang ditentukan yaitu 75. Hal tersebut menunjukkan bahwa sebagian besar siswa tidak dapat menerima materi program linear dengan baik.

Berdasarkan permasalahan yang ditemukan pada saat penelitian dan pengumpulan data maka selanjutnya melaksanakan pengembangan jenis/bentuk produk awal. Sebelum membuat pengembangan jenis/bentuk produk awal, terlebih dahulu disiapkan perencanaan garis besar isi bahan ajar elektronik. Setelah perencanaan dilakukan, maka dimulai membuat bahan ajar elektronik menggunakan aplikasi kvisoft flipbook maker.

Bahan ajar elektronik yang sudah dikembangkan dinilai oleh 8 validator untuk mengetahui valid atau tidaknya bahan ajar elektronik yang dikembangkan. Berdasarkan hasil validasi bahan ajar elektronik yang dilakukan oleh 8 validator maka diperoleh rata-rata total kriteria dari validator $V_{a}=4,1$. Menurut kriteria validasi maka dapat disimpulkan bahwa bahan ajar elektronik berbasis flipbook maker pada materi program linear kelas X SMK dikatakan valid. Hal tersebut membuktikan bahwa bahan ajar elektronik berbasis flipbook maker pada materi program linear kelas X SMK layak di uji cobakan. 
Uji pelaksanaan lapangan dilakukan setelah bahan ajar elektronik tersebut direvisi sesuai dengan saran yang telah diberikan oleh 8 validator. Uji coba dilakukan di SMK Muhammadiyah Kesesi yaitu kelas X TKR 2 sebanyak 28 siswa putra. Proses uji coba dilaksanakan dengan menerapkan metode pembelajaran Cooperative Integrated Reading and Composition (CIRC). Metode tersebut merupakan salah satu bentuk dari model pembelajaran kooperatif atau model pembelajaran berkelompok. Angket respon siswa diberikan kepada siswa setelah proses pembelajaran menggunakan bahan ajar elektronik. Angket tersebut diberikan kepada siswa untuk mengetahui kepraktisan bahan ajar elektronik yang telah dikembangkan. Berdasarkan pengamatan selama proses uji coba bahan ajar elektronik siswa sangat antusias mengikuti pembelajaran matematika. Hal tersebut terbukti ketika siswa megisikan angket, siswa menuliskan pesan seperti pada gambar di bawah ini.

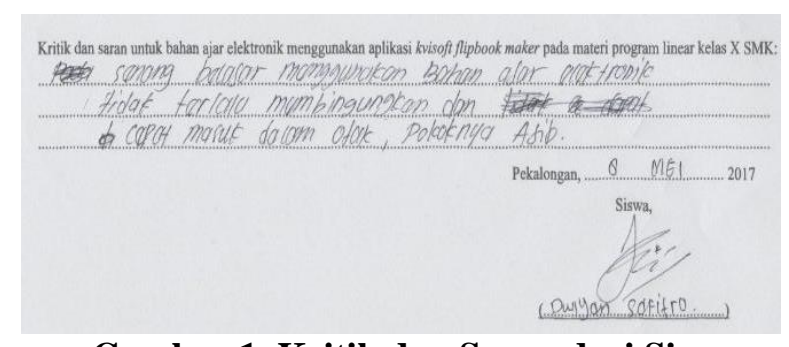

Gambar 1. Kritik dan Saran dari Siswa

Angket yang diisikan siswa terdapat juga kritik mengenai penggunaan bahan ajar elektronik pada saat proses pembelajaran. Salah satu kritik siswa yaitu bahwa layar bahan ajar elektronik kurang besar. Berdasarkan kritik yang diberikan tentang ukuran layar, hal tersebut merupakan salah satu kekurangan dari aplikasi yang digunakan untuk membuat bahan ajar elektronik.

Adapun kelebihan dari bahan ajar elektronik ini yaitu 1) isi bahan ajar elektronik yang meliputi materi dan latihan soal disajikan bervariasi tidak hanya teks tetapi terdapat gambar serta video yang mendukung materi, hal tersebut ditunjukkan dari hasil analisis data lembar validasi diperoleh kriteria isi bahan ajar elektronik mencapai nilai rata-rata kriteria atau $\mathrm{Ki} \square$ 4, 3 nilai rata-rata kriteria tersebut merupakan nilai rata-rata kriteria tertinggi dibandingkan nilai rata-rata kriteria lainnya; 2) bahan ajar elektronik memudahkan siswa belajar pada bagian tertentu sesuai yang diinginkan, hal ini ditunjukkan dari hasil analisis data angket respon siswa diperoleh jumlah skor yang diberikan siswa terhadap pernyataan 1 atau P1 yaitu 134 jumlah tersebut merupakan jumlah tertinggi dibandingkan dengan jumlah skor pada pernyataan lainnya. Adapun kelemahan dari bahan ajar elektronik ini yaitu ukuran layar bahan ajar elektronik, sehingga isi bahan ajar tidak bisa dilihat jelas, untuk memperjelas harus menggunakan fitur zoom pada bagian tertentu yang ingin dilihat. Hal ini ditunjukkan dari hasil analisis data lembar validasi dan angket 
respon siswa, skor terendah yang diberikan oleh validator dan siswa diperoleh pada bagian kriteria teknis yang meliputi ukuran huruf, gambar, dan sebagainya.

Berdasarkan hasil perhitungan nilai kepraktisan bahan ajar elektronik berbasis flipbook maker pada materi program linear kelas X SMK yang diperoleh dari angket respon siswa adalah 85,9 \%. Hal tersebut berarti bahwa bahan ajar elektronik yang dikembangkan dinyatakan praktis. Oleh karena itu, dapat disimpulkan bahwa bahan ajar elektronik berbasis flipbook maker pada materi program linear kelas X SMK valid dan praktis apabila digunakan sebagai salah satu sumber belajar.

Penyempurnaan produk akhir, pada langkah ini dilakukan perbaikan bahan ajar elektronik berdasarkan saran dan masukan yang diberikan siswa setelah uji pelaksanaan lapangan. Bahan ajar elektronik dikemas dalam CD (Compact Disk) agar lebih menarik serta mudah untuk disimpan dan dapat dibuka secara offline, tidak hanya itu bahan ajar elektronik juga di upload ke internet apabila siswa maupun guru ingin menggunakan bahan ajar elektronik secara online.

\section{Kesimpulan}

Berdasarkan hasil penelitian yang telah dilakukan maka dapat disimpulkan bahwa :

1. Bahan ajar elektronik berbasis flipbook maker pada materi program linear kelas X SMK valid. Hal tersebut terbukti dari hasil rata-rata total kriteria dari validator $V_{a}=4,1$.

2. Respon siswa terhadap bahan ajar elektronik berbasis flipbook maker pada materi program linear kelas X SMK praktis. Hal tersebut terbukti dari hasil angket respon siswa adalah $85,9 \%$.

Berdasarkan penelitian yang telah dilakukan, maka terdapat saran yang diberikan peneliti yaitu sebagai berikut.

1. Bahan ajar masih ada kekurangan mengenai ukuran layar oleh karena itu bagi penelitian selanjutnya agar bisa mengembangkan bahan ajar elektronik dengan hasil yang lebih baik dan memberikan solusi untuk mengatasi kekurangan dari bahan ajar ini.

2. Membuat bahan ajar elektronik berbasis flipbook maker ada yang perlu diperhatikan yaitu pada saat mendownload aplikasi flipbook maker karena ada salah satu program flipbook maker menggunakan trial, oleh karena bagi penelitian selanjutnya agar bisa lebih teliti dalam hal mendownload aplikasi yang akan digunakan untuk membuat bahan ajar elektronik. 


\section{Daftar Pustaka}

Daryanto. 2013. Media Pembelajaran. Yogyakarta: Gava Media.

Daryanto dan Aris Dwicahyono. 2014. Pengembangan Perangkat Pembelajaran. Yogyakarta: Gava Media.

Halimah, Andi. 2014. "Metode Cooperative Integrated Reading and Composition (CIRC) dalam Pembelajaran Membaca dan Menulis di SD/MI". Auladuna, 1, 27-35.

Jhonson dan Hamonangan Tambunan. 2014. "Pengembangan Media Pembelajaran Interaktif Berbasis Visual Basic dan Smoothboard pada Matematika”. Jurnal Teknologi Informasidan Komunikasi dalam Pendidikan, 1, 98-

109.

Liana, Nur. 2014. "Pengembangan Modul Pembelajaran Berbantu Flip Book Maker dengan Menggunakan Model Pembelajaran Two Stay Two Stray (TSTS) Materi Pokok Limit Fungsi Kelas XI". Prosiding Mathematics and Sciences Forum, 557-564.

Putra, Nusa. 2012. Research and Development. Jakarta: Raja Grafindo Persada.

Sam’s, Rosman Hartiny. 2010. Model Penelitian Tindakan Kelas. Yogyakarta: Teras.

Sugianto, Dony, Ade Gafar Abdullah, Siscka Elvyanti, dan Yuda Muladi. 2013. "Modul Virtual: Multimedia Flipbook Dasar Teknik Digital”. Invotec, IX, 101-116.

Sugiyono. 2010. Metode Penelitian Pendidikan. Bandung: Alfa Beta.

Trianto. 2009. Mendesain Model Pembelajaran Inovatif-Progresif. Jakarta: Kencana.

Wahyudi. 2012. "Pengembangan Bahan Ajar Elektronik Multimedia dengan Macromedia Flash 8.0 untuk Mahasiswa S1 PGSD UKSW”. Satya Widya, 28, 55-72. 